\title{
Using Student Data Analysis Based on Eduinformatics for Criteria in Institutional Research
}

\author{
Kunihiko Takamatsu *, Katsuhiko Murakami ${ }^{\dagger}$, \\ Yasuhiro Kozaki *, Aoi Kishida \$, \\ Takafumi Kirimura **, Kenya Bannaka *, \\ Ikuhiro Noda *, Kenichiro Mitsunari *, \\ Masato Omori *, Yasuo Nakata *
}

\begin{abstract}
"Eduinformatics" is a new field of education that combines both education and informatics. In this article, we propose new criteria by which to utilize university student data in Institutional Research (IR). We define "primary data," which is uncombined data and "secondary data," which is a combination of primary or secondary data. Moreover, we present examples in which primary data were used to detect elements that could not be founded through the analysis of secondary data and were pitfalls of comparative analysis performed by IR practitioners.
\end{abstract}

Keywords: educational innovation, eduinformatics, primary data, secondary data.

\section{Introduction}

More than 15 years ago, the human genome consortium, which consists of many researchers from all over the world, sequenced the whole human genome. The human genome includes approximately three gigabytes of base pairs. Many informaticians joined the human genome project, adding the two fields of computers and informatics to the project when the original researchers found the data impossible to analyze manually. This phenomenon led to the creation of a novel interdisciplinary field called bioinformatics, which is so named because it combines the two fields of biology and informatics.

Recently, research on higher education has increased greatly. Additionally, Japanese Universities have promoted the establishment of Institutional Research (IR). This situation is

\footnotetext{
* Kobe Tokiwa University, Hyogo, Japan

$\uparrow$ The University of Tokyo, Tokyo, Japan

* Osaka Kyoiku University, Osaka, Japan

$\S$ Kobe City Nishi-Kobe Medical Center, Hyogo, Japan

${ }^{* *}$ Hirosaki University, Aomori, Japan
} 
similar to the era of bioinformatics' development, especially since much educational research is "evidence-based," similar to evidence-based medicine. However, this type of research is extremely difficult to undertake with conventional pedagogical techniques alone. Higher education could develop dramatically if researchers would apply informatics to their data. Doing so would contribute greatly to statistics, machine learning (AI), data science, and so on, just as biology developed dramatically with the advent of bioinformatics.

"Eduinformatics" is a new field of education that combines both education and informatics [1]. It is a portmanteau of "education" and "informatics." Eduinformatics not only deals with students' data, but it also provides new analysis methods and concepts to deal with data in education, similar to bioinformatics. As a part of our project, we reviewed the existing research in Eduinformatics [2]. In this review, we included the following research points. The first point involved prediction by machine learning [3]. We predicted the probability of student dropouts using machine learning [3]. The second point involved visualization curricula. We developed a novel curriculum visualization method-Dynamic Curriculum Mapping (DCM) - through a combination of cosine similarity, t-SNE, and scatter plotting [4].

To deal with student data, universities have a department called IR. Japan's Ministry of Education, Culture, Sports, Science and Technology (MEXT) published two high-profile reports on IR [5][6]. The number of IR offices in Japanese universities increased after these reports were published. Since 2016, there has been a strong requirement from MEXT for Japanese universities to establish IR departments.

In Japan, the International Conference on Data Science and Institutional Research (DSIR) is the only international meeting that deals with IR. Since 2016, we have published articles in DSIR $[7][8][9][3][4]$ that address the topics of collaborative research between faculty and staff and the application of bioinformatics in education.

This paper has two parts. The first is an introduction to three layers of learning analytics proposed by the United Nations Educational, Scientific and Cultural Organization (UNESCO). The three layers include macro, meso, and micro levels. Further, we propose new criteria for IR, including primary and secondary data. The second part provides examples in which primary data were used to detect elements that could not be founded through the analysis of secondary data and were pitfalls of comparative analysis performed by IR practitioners.

\section{Proposal of New Criteria}

\subsection{Introduction of three layers of learning analytics proposed by UNESCO}

UNESCO proposed the "three layers of learning analytics" in a report on learning analytics in 2012 [10] (Figure 1). The following are the definitions of the three layers of analytics [10]. Macro-level analyses investigate institutional analytics. For example, macro-level analyses are performed through "maturity" surveys of current institutional practices [11]. Moreover, macrolevel analyses are performed by improving state-wide data access to standardized assessment data over students' lifetimes [12]. In the future, macro-analytics will become increasingly realtime oriented, incorporating more data from the finer-granularity meso/micro levels, and could conceivably benefit from benchmarking and data integration methodologies developed in noneducational sectors. 


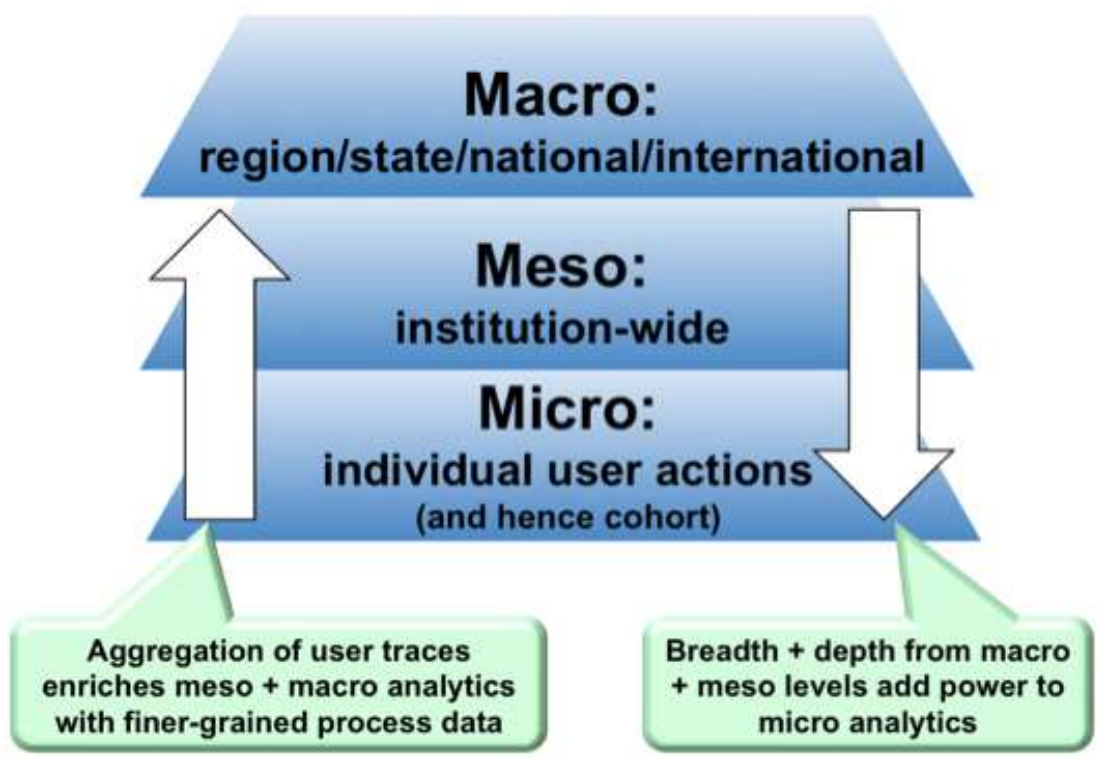

Figure 1: Layers of Learning Analytics from UNESCO IITE, Learning Analytics, 2012

Meso-level analytics deal with at the institutional level. It is important to expand educational institutions' shared business processes to sectors already benefiting from Business Intelligence (BI), creating a new BI market sector that can usefully appropriate tools. BI tools can investigate institutional level "academic analytics" [13].

Micro-level analytics deal with the tracking and analysis of process-level data for individual learners. These data are very important because by using them, students' data can be analyzed in real-time. An Institutional Researcher (IRer) can use students' personal data, such as online activity, click-by-click, as well as physical activity, such as geolocation, library loans, and purchases, and interpersonal data, such as social networks.

\subsection{Proposal of new criteria through "primary data" and "secondary data" for IR}

We define a linear function combination as follows.

For function $f_{1}, f_{2}, \ldots, f_{n}$ and scalar $a_{1}, a_{2}, \ldots, a_{n}$, we define the linear combination of $f_{1}, f_{2}, \ldots$, $f_{n}$, as

$$
a_{1} f_{1}+a_{2} f_{2}+\ldots+a_{n} f_{n}
$$

Therefore, a linear combination is the summation of the function $f$ times weight $a_{1}, a_{2}, \ldots, a_{n}$. Further, we define a linear map or function as follows.

For function or map $\mathrm{x}$ and $\mathrm{y}$, the linear map or function satisfies the following two properties.

$$
\text { Additivity: } f(x+y)=f(x)+f(y) \text {. }
$$

Homogeneity of degree 1: $f(a x)=a f(x)$ for all $a$.

When a map or function is linear, it is a linear combination. 


\subsection{Example of "primary data" and "secondary data" with layers for IR}

Now, we define primary data as those data that are neither linear nor nonlinear combination data; secondary data are both a linear and nonlinear combination of primary data. In other words, the definition of primary data is similar to that of original data, and the definition of secondary data is constructed as using primary or secondary data or a combination of primary and secondary data.

Examples of primary and secondary data at the micro-level are as follows:

- Primary data: correct and incorrect answers to examination questions or students' attendance in and absence from a lecture

- Secondary data: the total points in an examination or students' total attendance in and absence from a lecture

An example of primary and secondary data at the meso-level is as follows:

- Secondary data: Grade point average (GPA) of rank in the annual record of a university

GPA and rank in the annual record of the university, a linear function combination, are calculated using student records from lectures, which are secondary data.

Realistically, most secondary data for students in a university are calculated as linear from primary data. However, for example, in item response theory, the ability of students is calculated by maximum likelihood estimation (MLE). In this case, the value of the ability of students is clearly secondary data but not linear data because it was calculated by MLE.

Therefore, we have included the definition of secondary data to involve a linear as well as a nonlinear combination of primary data.

\section{Pilot Analysis of the Primary and Secondary Data}

\subsection{Preparatory introduction of example in primary and secondary data}

The Central Council for Education (CCE) is one of the councils belonging to the MEXT. In 2008, the CCE reported on the future of higher education in Japan [14]. The report proposed a collaborative operation between admission policy (AP), curriculum policy (CP), and diploma policy (DP).

The entire faculty of our university had existing definitions for each of the three policies. However, these policies did not have relationships with one another among the faculty. Most universities are in the same situation; that is, the three policies- $\mathrm{AP}, \mathrm{CP}$, and $\mathrm{DP}$ - have no relationship to one another [15].

Kobe Tokiwa University implemented an educational innovation organization in 2014, initiating an educational revolution that extended beyond the boundaries of departments and resulted in a comprehensive curriculum revolution in 2017 [16]. As a part of this revolution, we integrated AP, CP, DP, our original student support policy, and assessment policy (ASP) [16].

The original educational innovation organization applied to the semi-regular curriculum in addition to regular and nonregular curricula. In addition, it appointed 19 Tokiwa Competencies to these curricula [17]. 
Tokiwa has defined 19 types of competencies: Culture, Common Sense, Professionalism/Expertise, Media Literacy, Logical Thinking, Critical Thinking, Intellectual Curiosity, Exploration, Continuity, Self-management, Reflection, Conceptual Thinking, Presentation, Judgment, Implementation, Responsibility, Contribution, Communication, and Cooperation \& Collaboration. Students will obtain the competencies of Exploration, Reflection, Self-management, Conceptual Thinking, Presentation, and Cooperation \& Collaboration [8].

Moreover, we review a syllabus and demonstrate a clear relationship between the evaluation method and evaluation item using Tokiwa Competencies [18]. At the time of its 2017 institutional reform, Kobe Tokiwa University initiated a new first-year education course program titled "Manaburu" [19]. The word "Manaburu" is a portmanteau of the Japanese word for learning, "manabu," and the English suffix "able." As such, Manaburu indicates that "students are able to learn by themselves."

The 2018 syllabus of Manaburu I indicates that the abilities students will obtain are based on a combination of the Cooperation \& Collaboration, Exploration, Conceptual Thinking, Reflection, and Self-management components. Further, the rubrics for Manaburu I are defined for both students and teachers (Table 1) [19]. Evaluation matrices are also supplied for Manaburu I (Table 2) [19], according to the Tokiwa Competencies and their relationship with these rubrics.

\subsection{Statistical analysis software}

In this study, we used JMP version 13.2.1 to conduct the analyses. The significance level is five percent in the study. We mainly used JMP for analysis. However, JMP lacks some visualization features. For example, see Figure 3C and 3E.

Regarding statistical analysis, we used R [20] version 3.6.2 and RStudio version 1.2.5033 [21]. To visualize as a beeswarm for our data, we used the beeswarm package, version 0.2.3, for $\mathrm{R}$ [22].

\subsection{Example of analysis of secondary data}

Figure 2 presents a mosaic pattern of students' grade evaluations, from $\mathrm{S}$ to $\mathrm{C}$ of Manaburu I in 2018, classified from 20 teachers (A-T). We did not find significant differences in grade evaluations between faculty with the $\chi^{2}$ test $\left(\chi^{2}(x)=73.194, p=0.0730\right)$.

Next, we proposed analyzing the plane point, which was the base of the grades. First, we performed the Shapiro-Wilk W test to choose the analysis method: parametric or nonparametric. The null hypothesis is "ordered parametric," and the alternative hypothesis is "not ordered parametric."

Consequently, the $\mathrm{p}$ value of each teacher is as follows. A: $p=0.002$, B: $p=0.648$, C: $p=$ $0.041, \mathrm{D}: p=0.108, \mathrm{E}: p=0.635, \mathrm{~F}: p=0.053, \mathrm{G}: p=0.453, \mathrm{H}: p=0.093, \mathrm{I}: p=0.004, \mathrm{~J}: p=$ $0.015, \mathrm{~K}: p=0.421, \mathrm{~L}: p=0.008, \mathrm{M}: p=0.137, \mathrm{~N}: p=0.349, \mathrm{O}: p=0.231, \mathrm{P}: p=0.779, \mathrm{Q}: p=$ $0.061, \mathrm{R}: p=0.258, \mathrm{~S}: p=0.025, \mathrm{~T}: p=0.779$. 
Table 1: Rubrics of Manaburu I (2018) from [8]

\begin{tabular}{|c|c|c|c|c|c|c|}
\hline \multicolumn{2}{|c|}{$\begin{array}{r}\text { Grade } \\
\text { Competency }\end{array}$} & \multirow{2}{*}{$\begin{array}{l}\mathbf{0} \\
\text { Cannot fulfil role } \\
\text { assigned to one- } \\
\text { self. }\end{array}$} & \multirow{2}{*}{$\begin{array}{l}1 \\
\text { Cannot fulfil role } \\
\text { assigned to one- } \\
\text { self. }\end{array}$} & \multirow{2}{*}{$\begin{array}{l}2 \\
\text { Knows one's role } \\
\text { in the group and } \\
\text { fulfills it. }\end{array}$} & \multirow[b]{2}{*}{$\begin{array}{l}3 \\
\text { While listening to } \\
\text { others' opinions, } \\
\text { knows one's role } \\
\text { in the group and } \\
\text { fulfills it, and can } \\
\text { explain the need } \\
\text { for the role to } \\
\text { others. }\end{array}$} & \multirow[b]{2}{*}{$\begin{array}{l}4 \\
\text { Listening to oth- } \\
\text { ers' opinions, } \\
\text { knows one's role } \\
\text { in the group, can } \\
\text { explain its im- } \\
\text { portance to others } \\
\text { in the group, and } \\
\text { fulfills it for } \\
\text { group members, } \\
\text { contributing to } \\
\text { group perfor- } \\
\text { mance. }\end{array}$} \\
\hline & $\begin{array}{l}\text { Cooperation } \& \\
\text { Collaboration }\end{array}$ & & & & & \\
\hline & Exploration & $\begin{array}{l}\text { Is satisfied with } \\
\text { the solutions } \\
\text { given by others } \\
\text { for the assign- } \\
\text { ments. }\end{array}$ & $\begin{array}{l}\text { Is satisfied by } \\
\text { contributing one } \\
\text { idea (opinion) to } \\
\text { the assignment. }\end{array}$ & $\begin{array}{l}\text { Contributes an } \\
\text { idea (opinion) to } \\
\text { the group assign- } \\
\text { ment using multi- } \\
\text { directional } \\
\text { thought, and can } \\
\text { explain the rea- } \\
\text { son for their } \\
\text { thinking. }\end{array}$ & $\begin{array}{l}\text { Contributes some } \\
\text { ideas (opinions) } \\
\text { to the group as- } \\
\text { signment using } \\
\text { multidirectional } \\
\text { thought, and can } \\
\text { logically explain } \\
\text { which idea (opin- } \\
\text { ion) is most ef- } \\
\text { fective for solv- } \\
\text { ing the problem. }\end{array}$ & $\begin{array}{l}\text { Contributes an } \\
\text { idea (opinion) to } \\
\text { the assignment } \\
\text { using multidirec- } \\
\text { tional thought, } \\
\text { and can logically } \\
\text { explain which } \\
\text { idea (opinion) is } \\
\text { most effective in } \\
\text { solving the prob- } \\
\text { lem and predict- } \\
\text { ing the results. }\end{array}$ \\
\hline & Presentation & $\begin{array}{l}\text { Cannot com- } \\
\text { municate own } \\
\text { ideas or initia- } \\
\text { tives to others. }\end{array}$ & $\begin{array}{l}\text { Can communi- } \\
\text { cate own ideas or } \\
\text { initiatives to oth- } \\
\text { ers. }\end{array}$ & $\begin{array}{l}\text { Can organize } \\
\text { ideas and initia- } \\
\text { tives for others to } \\
\text { understand, and } \\
\text { discuss them with } \\
\text { group members. }\end{array}$ & $\begin{array}{l}\text { Can show how } \\
\text { own ideas and in- } \\
\text { itiatives differ } \\
\text { from those of oth- } \\
\text { ers in a clear and } \\
\text { objective manner. }\end{array}$ & $\begin{array}{l}\text { Can communi- } \\
\text { cate own ideas } \\
\text { and initiatives } \\
\text { and how they dif- } \\
\text { fer from others in } \\
\text { a clear and objec- } \\
\text { tive manner, in- } \\
\text { cluding what it } \\
\text { means to their op- } \\
\text { ponent. }\end{array}$ \\
\hline & Reflection & $\begin{array}{lr}\text { Cannot } & \text { explain } \\
\text { what } & \text { was } \\
\text { learned. } & \end{array}$ & $\begin{array}{l}\text { Can explain what } \\
\text { was learned. }\end{array}$ & $\begin{array}{l}\text { Can reflect on } \\
\text { what was learned } \\
\text { and can explain } \\
\text { what it means to } \\
\text { them (reflect on } \\
\text { learning collec- } \\
\text { tively). }\end{array}$ & $\begin{array}{l}\text { Can explain the } \\
\text { results of learn- } \\
\text { ing together with } \\
\text { own issues and } \\
\text { future growth } \\
\text { (can link learning } \\
\text { to their own } \\
\text { growth). }\end{array}$ & $\begin{array}{l}\text { Can explain the } \\
\text { results of learn- } \\
\text { ing together with } \\
\text { own tasks and fu- } \\
\text { ture growth, and } \\
\text { can show con- } \\
\text { crete guidelines } \\
\text { on overcoming } \\
\text { issues and growth } \\
\text { from the results } \\
\text { of learning. }\end{array}$ \\
\hline $\mathbf{V}$ & Self-Management & $\begin{array}{l}\text { Does not meet the } \\
\text { basic require- } \\
\text { ments of learning } \\
\text { and study habits, } \\
\text { for example can- } \\
\text { not submit as- } \\
\text { signments by due } \\
\text { dates and/or does } \\
\text { not contribute to } \\
\text { group activities. }\end{array}$ & $\begin{array}{l}\text { Meets the basic } \\
\text { requirements of } \\
\text { learning and } \\
\text { study habits, for } \\
\text { example submits } \\
\text { assignments by } \\
\text { due dates and/or } \\
\text { actively engages } \\
\text { in group activi- } \\
\text { ties. }\end{array}$ & $\begin{array}{l}\text { Meets all require- } \\
\text { ments of learning } \\
\text { and study habits } \\
\text { according to own } \\
\text { learning } \\
\text { style/needs, for } \\
\text { example tackles } \\
\text { issues on a } \\
\text { planned basis, } \\
\text { adjusts to an en- } \\
\text { vironment suita- } \\
\text { ble for activities. }\end{array}$ & & \\
\hline & Design Thinking & $\begin{array}{l}\text { Does not contrib- } \\
\text { ute any ideas to } \\
\text { group assign- } \\
\text { ments. }\end{array}$ & $\begin{array}{l}\text { Contributes basic } \\
\text { ideas to group as- } \\
\text { signments. }\end{array}$ & $\begin{array}{l}\text { Contributes crea- } \\
\text { tive ideas to } \\
\text { group assign- } \\
\text { ments. }\end{array}$ & $\begin{array}{l}\text { Contributes orig- } \\
\text { inal ideas to } \\
\text { group assign- } \\
\text { ments that have } \\
\text { not been seen } \\
\text { elsewhere. }\end{array}$ & $\begin{array}{l}\text { Contributes orig- } \\
\text { inal ideas that can } \\
\text { be objectively } \\
\text { evaluated on a so- } \\
\text { cial scale to } \\
\text { group assign- } \\
\text { ments. }\end{array}$ \\
\hline
\end{tabular}


Table 2: Evaluation Matrix of Manaburu I (2018) from [8]

\begin{tabular}{|c|c|c|c|c|c|c|c|c|}
\hline & & $\begin{array}{c}\text { I } \\
\text { Cooperation } \\
\& \\
\text { Collaboration } \\
\end{array}$ & $\begin{array}{c}\text { II } \\
\text { Exploration }\end{array}$ & $\begin{array}{c}\text { III } \\
\text { Presentation }\end{array}$ & $\begin{array}{c}\text { IV } \\
\text { Reflection }\end{array}$ & $\begin{array}{c}\mathrm{V} \\
\text { Self- } \\
\text { Management }\end{array}$ & $\begin{array}{c}\text { VI } \\
\text { Design } \\
\text { Thinking }\end{array}$ & $\begin{array}{l}\text { Total } \\
\text { Score }\end{array}$ \\
\hline \multirow{2}{*}{$\begin{array}{l}\text { Assignment } \\
\text { Report }\end{array}$} & Midterm & & \begin{tabular}{l}
\multicolumn{1}{c}{1} \\
$0: 0$ point \\
$1: 1-2$ point \\
$2: 3$ point \\
$3: 4$ point \\
$4: 5$ point \\
\end{tabular} & & $\begin{array}{c} \\
0: 0 \text { point } \\
1: 1-2 \text { point } \\
2: 3 \text { point } \\
3: 4 \text { point } \\
4: 5 \text { point } \\
\end{array}$ & & & 10 \\
\hline & Final & & $\begin{array}{l}\quad 3 \\
0: 0 \text { point } \\
\text { 1: } 1-2 \text { point } \\
\text { 2:3 point } \\
\text { 3:4 point } \\
\text { 4: } 5 \text { point } \\
\end{array}$ & & $\begin{array}{l}\quad 4 \\
0: 0 \text { point } \\
1: 1-2 \text { point } \\
2: 3 \text { point } \\
3: 4 \text { point } \\
4: 5 \text { point } \\
\end{array}$ & & & 10 \\
\hline \multicolumn{2}{|l|}{ Portfolio } & $\begin{array}{c}5 \\
0: 0 \text { point } \\
1: 2 \text { point } \\
2: 3 \text { point } \\
3: 4 \text { point } \\
4: 5 \text { point } \\
\end{array}$ & $\begin{array}{c}\quad 6 \\
0: 0 \text { point } \\
1: 3-5 \text { point } \\
\text { 2: } 5-8 \text { point } \\
\text { 3: } 9 \text { point } \\
\text { 4: } 10 \text { point }\end{array}$ & & \begin{tabular}{l}
\multicolumn{1}{c}{7} \\
$0: 0$ point \\
$1: 6-8$ point \\
$2: 9-11$ point \\
3: $12-14$ point \\
4: 15 point \\
\end{tabular} & & & 30 \\
\hline \multicolumn{2}{|c|}{$\begin{array}{l}\text { Other (Group Activities, } \\
\text { etc.) }\end{array}$} & \begin{tabular}{l}
\multicolumn{1}{c}{8} \\
$0: 0$ point \\
$1: 6-8$ point \\
$2: 9-11$ point \\
3: $12-14$ point \\
4: 15 point
\end{tabular} & & \begin{tabular}{l}
\multicolumn{1}{c}{9} \\
$0: 0$ point \\
$1: 6-8$ point \\
$2: 9-11$ point \\
3: $: 12-14$ point \\
4: 15 point
\end{tabular} & & $\begin{array}{r}10 \\
0: 0 \text { point } \\
1: 8 \text { point } \\
2: 10 \text { point }\end{array}$ & $\begin{array}{c}11 \\
0: 0 \text { point } \\
1: 3-5 \text { point } \\
2: 5-8 \text { point } \\
3: 9 \text { point } \\
4: 10 \text { point } \\
\end{array}$ & 50 \\
\hline \multicolumn{2}{|l|}{ Total Score } & 20 & 20 & 15 & 25 & 10 & 10 & 100 \\
\hline
\end{tabular}

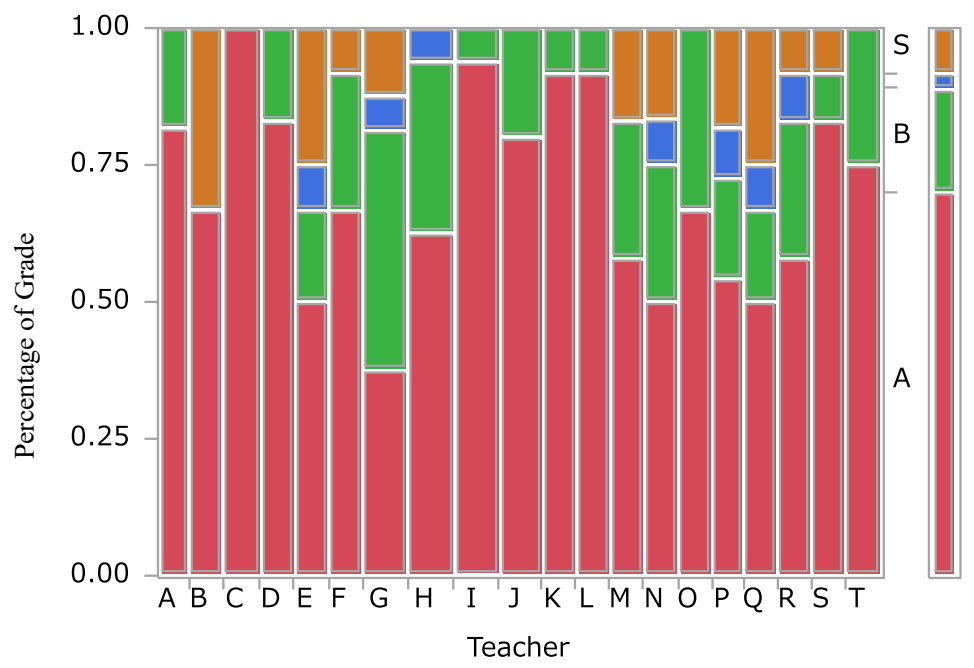

Figure 2: Distribution of grade of Manaburu I in 2018 by 20 teachers from A to T. Orange, red, green, and blue colors show $\mathrm{S}, \mathrm{A}, \mathrm{B}$, and $\mathrm{C}$ grade, respectively. 
It can be concluded that teachers A, C, I, J, L, and S have no normality, while the others have normality. These results indicate that nonparametric analysis should be performed when we undertake multiple comparisons on all pairs.

Thus, we performed nonparametric multiple comparisons of all teachers. In this case, we used the Wilcoxon/Kruskal-Wallis rank sum test as a nonparametric method. The result indicated that there were significant differences $(p=0.0493)$.

Next, we performed the Steel-Dwass test, which is a nonparametric multi-comparison test applied to all combinations (pairs), in which we found significance between faculties " $\mathrm{B}$ " and "H" $(p=0.0264)$.

\subsection{Comparison of visualization of data}

If a significant difference is observed, as in this case, we must check the distribution of the data. However, when comparing and analyzing the data, IR practitioners should avoid using bar graphs in the form of a mean. We will explain this based on actual examples in which the original distribution of data can be intuitively understood by illustrating it in figures, violin plots, and box plots. See Figures 3A through 3E for further explanation.

Figure $3 \mathrm{~A}$ represents the mean and standard deviation using bar graphs and an error bar. It was difficult to recognize the distribution beyond this.

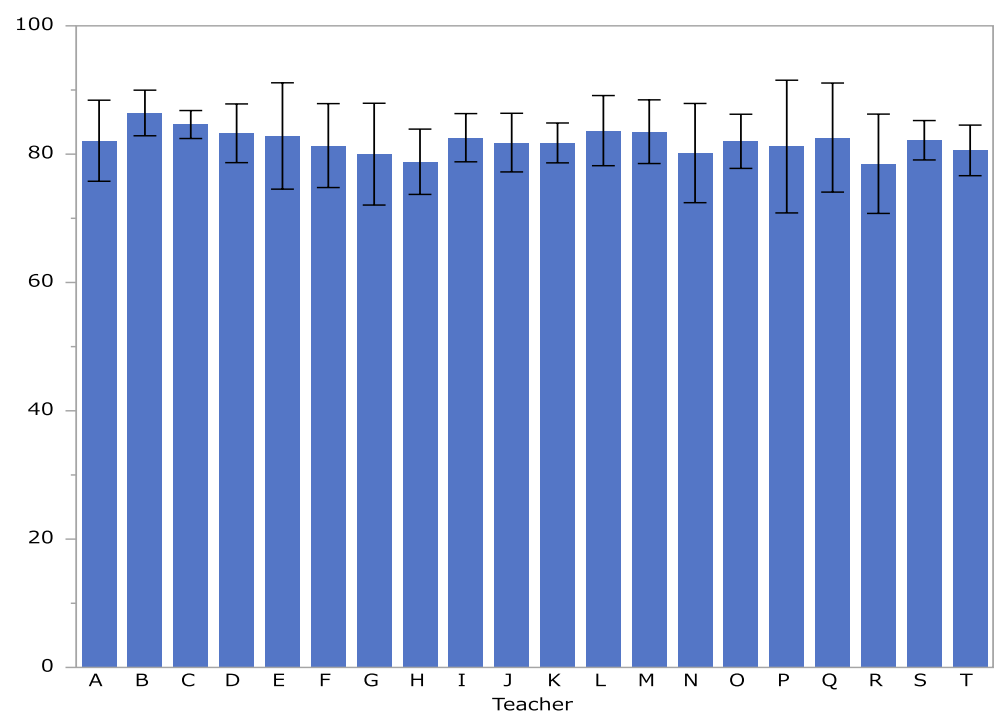

Figure 3A: Bar graph using mean and standard deviation by 20 teachers from A to T 
Figure 3B presents a box plot that enhances those deviations, thus offering a more obvious juxtaposition as compared to Figure 3A.

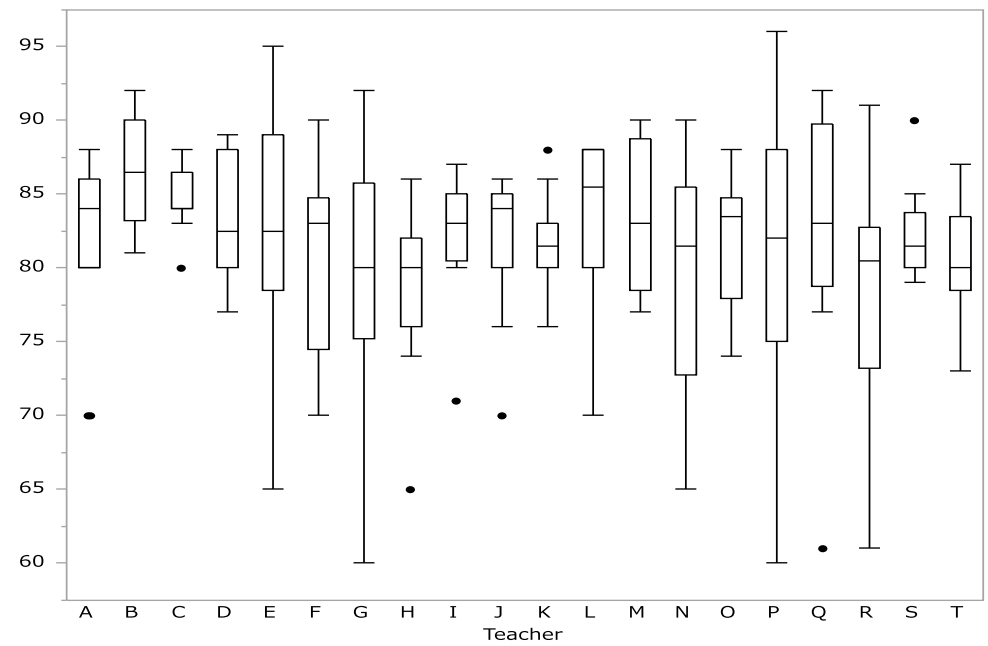

Figure 3B: Box plot by 20 teachers from A to $\mathrm{T}$

Figure $3 \mathrm{C}$ is a violin plot. The feather of a violin plot can illustrate density. As it marks the density of each value by teachers, we can understand the original distribution more easily, as compared to Figures 3A or 3B.

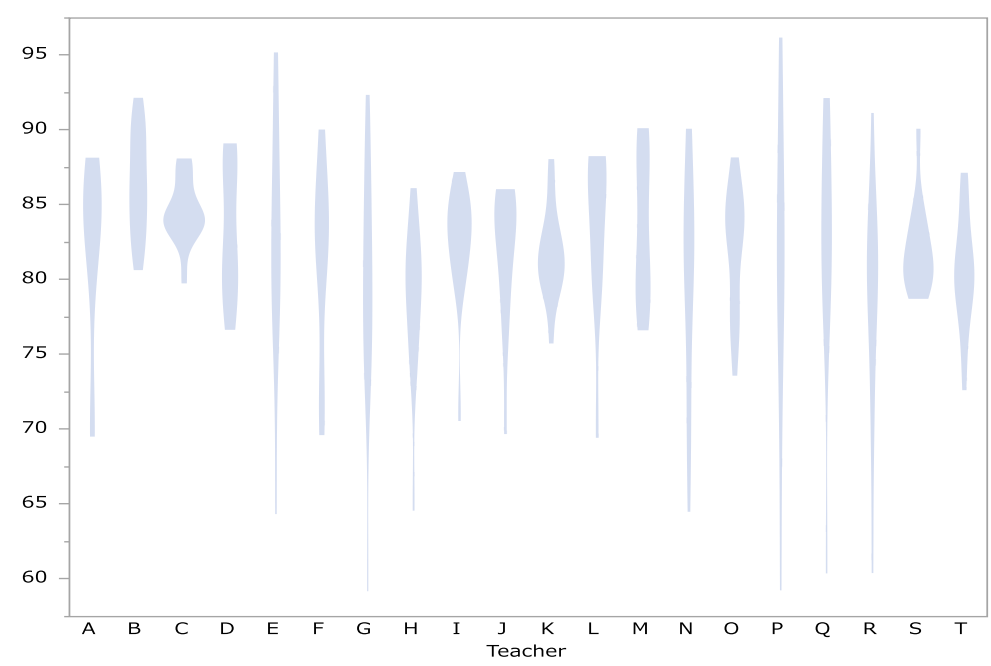

Figure 3C: Violin plot by 20 teachers from A to $\mathrm{T}$

Figure 3D is a scatter plot. A standard scatter plot cannot illustrate the density of original data because, if there are entries with the same value, in a scatter plot we can only locate a dot as more than one sample. 


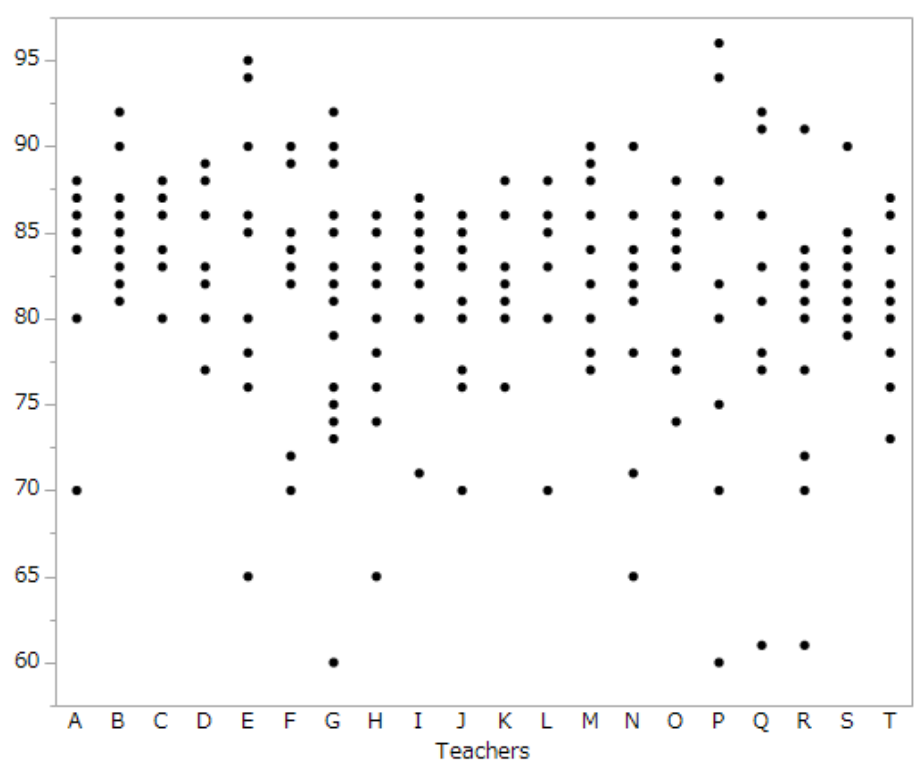

Figure 3D: Scatter plot by 20 teachers from $\mathrm{A}$ to $\mathrm{T}$

To resolve this problem, a beeswarm plot was recently developed [22]. We present a beeswarm plot in Figure 3E, which can express density if the same value exists, indicated by a slight movement of the plot point on the $\mathrm{x}$-axis.

Departments of IR in universities have not only faculty but also staff. Therefore, we must carefully consider which type of data presentation is most effective.

It is commonly known that scatter plots (Figure 3D), beeswarm plots (Figure 3E), or violin plots (Figure 3C) are preferable to bar graphs (Figure 3A) or box plots (Figure 3B) [23]. To understand the original distribution of the data, we concluded that the best illustration to enable clear visualization of the data is a scatter plot.

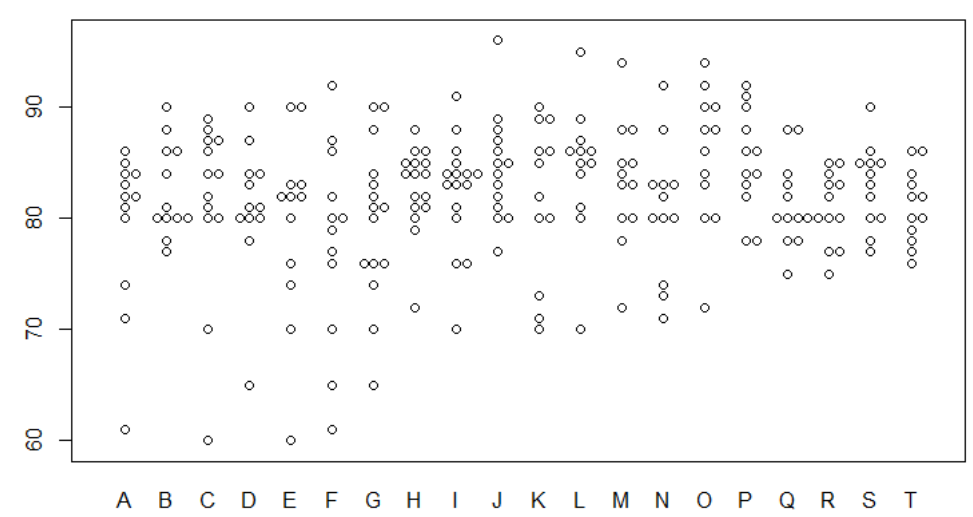

Figure 3E: Beeswarm plot by 20 teachers from A to T 


\subsection{Example analysis of primary data and comparison between primary and sec- ondary data}

Next, we will present an example that can detect elements using primary data that could not be found through an analysis of secondary data. We have already indicated that we found a significant variance between faculty " $\mathrm{B}$ " and " $\mathrm{H}$ " $(p=0.0264)$ by applying the Steel-Dwass test. The number of whole pairs of each teacher was ${ }_{20} \mathrm{C}_{2}=190$. This result indicated that, except for the pair of $\mathrm{B}$ and $\mathrm{H}$, we could not detect a strong difference between teachers. In this analysis, we used a total score based on the grades of students. In Table 2, we present the evaluation matrix of Manaburu I in 2018.

The total score in Table 2 presents the combined data of 11 items involved: 1. I Cooperation \& Collaboration - Portfolio, 2. I Cooperation \& Collaboration • Other (Group Activities, etc.), 3. II Exploration • Midterm Assignment Report, 4. II Exploration • Final Assignment Report, 5. II Exploration • Portfolio, 6. III Presentation • Other (Group Activities, etc.), 7. IV Reflection • Midterm Assignment Report, 8. IV Reflection - Final Assignment Report, 9. IV Reflection • Portfolio, 10. V Self-management - Other (Group Activities, etc.), and 11. VI Conceptual Thinking $\cdot$ Other (Group Activities, etc.). Thus, we can deal with the total score as secondary data.

On the other hand, we can treat each of the 11 items as primary data. By using the Steel-Dwass test, excepting the pair of $\mathrm{B}$ and $\mathrm{H}$, we cannot detect a strong difference between teachers. This means that when using secondary data, our analysis cannot detect problems in the evaluation of students by teachers.

Now, we will use primary data-11 items - for our analysis. In Figure 4, we illustrate the standard deviations of 11 items by teachers as a scatter plot. As described above, it is important to illustrate the data using a scatter plot to facilitate visualization and understanding of the original distribution of these data. The number of dots associated with Teacher $\mathrm{L}$ is less than that of the

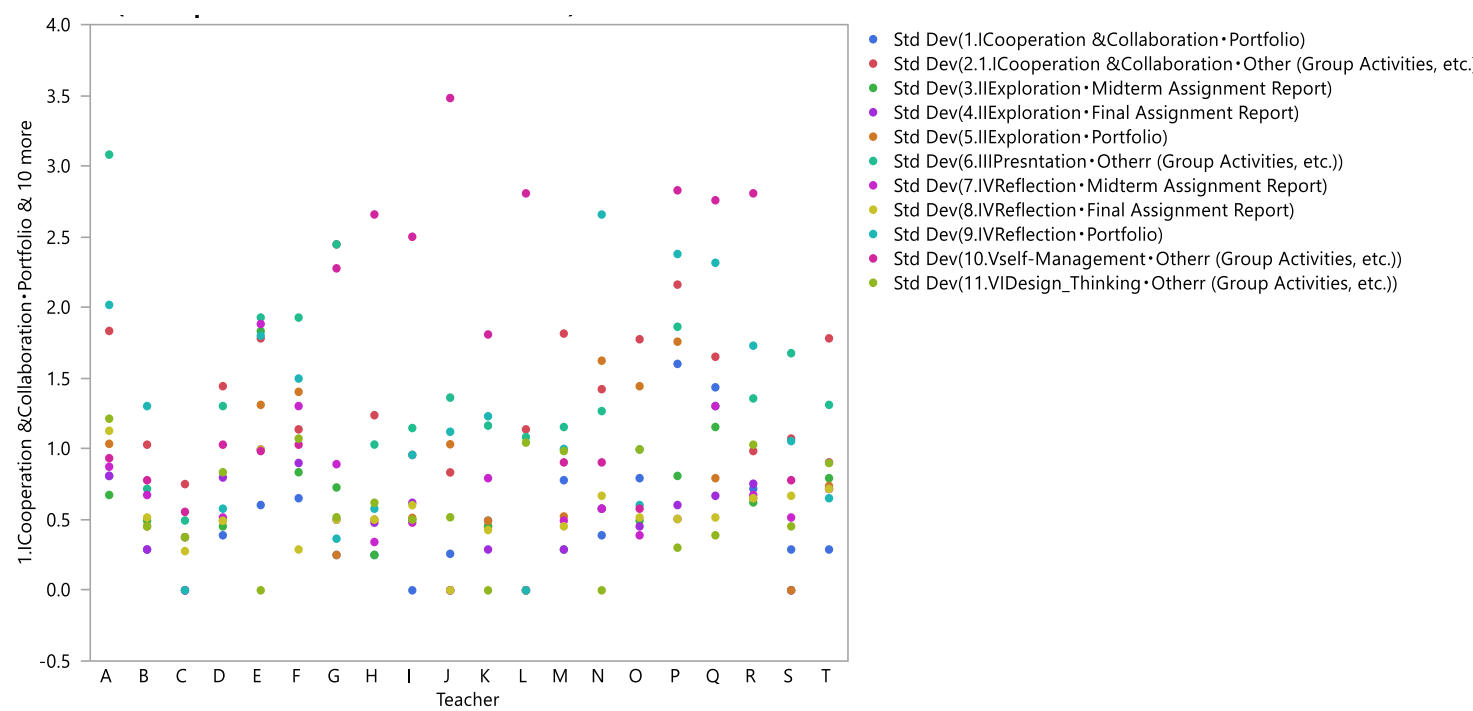

Figure 4: Standard deviation by teachers for 11 value of evaluation matrix in Table 2 for Manaburu I in 2018 
other teachers. Thus, next, we check the original values of the 11 items of Teacher L. The result indicates that the standard deviation of the following seven items is 0: 1. I Cooperation \& Collaboration • Portfolio, 3. II Exploration • Midterm Assignment Report, 4. II Exploration • Final Assignment Report, 5. II Exploration • Portfolio, 7. IV Reflection • Midterm Assignment Report, 8. IV Reflection - Final Assignment Report, 9. IV Reflection - Portfolio. Further, the standard deviation of the following four items is 1.14, 1.08, 2.81, and 1.04, respectively: 2. I Cooperation \& Collaboration - Other (Group Activities, etc.), 6. III Presentation - Other (Group Activities, etc.), 10. V Self-management - Other (Group Activities, etc.), and 11. VI Conceptual Thinking • Other (Group Activities, etc.). This result demonstrates that evaluation for students by Teacher $\mathrm{L}$ is the same Assignment Report and portfolio except for Other (Group Activities, etc.).

In Manaburu I 2018, two teachers partnered to teach students in the same classroom-Teacher $\mathrm{K}$ was paired with Teacher L. However, the standard deviation of Teacher $\mathrm{K}$ for the 11 items was 0 in 11. VI Conceptual Thinking - Other (Group Activities, etc.). This means that students of Teacher L had especially strong uniformity. This analysis suggests that the evaluation of Teacher $\mathrm{L}$ for student evaluations has some problems.

\subsection{Importance of distinguishing between primary and secondary data for IR in Eduinformatics}

In this study, through a close examination of Manaburu I in 2018, we demonstrated that analysis using secondary data cannot detect problems of evaluation, but analysis using primary data can. In addition, we indicated that when IR staff analyze and illustrate data to comprehend the original distribution of data, it is more effective to utilize a scatter plot, violin plot, or beeswarm plot rather than a bar graph or box plot.

This study is a prototype study of assessment for higher education. Our past research in Eduinformatics [8][4][24][25][26][27] created a new movement for the visualization of learning outcomes at Kobe Tokiwa University. Our research team not only inspired the visualization of learning outcomes among Kobe Tokiwa University faculty and staff but also gained the support of students and graduates at the university. This novel team will facilitate university development, promote IR, and encourage university reform.

This article was written for presentation in both DSIR2019 [28] and DSIR2020 [29].

\section{References}

[1] K. Takamatsu et al., "'Eduinformatics': A new education field promotion," Bull. kobe Tokiwa Univ., vol. 11, pp. 27-44, 2018.

[2] K. Takamatsu et al., "Review of Recent Eduinformatics Research," in IEEE/IIAI International Congress on Applied Information Technology, 2019, pp. 27-32.

[3] K. Murakami et al., "Predicting the Probability of Student Dropout through EMIR Using Data from Current and Graduate Students," in Advanced Applied Informatics (IIAI-AAI), 2018 7th International Institute of Applied Informatics (IIAI) International Congress on. Institute of Electrical and Electronics Engineers (IEEE), 2018, pp. $478-481$. 
[4] K. Takamatsu et al., "A New Way of Visualizing Curricula Using Competencies : Cosine Similarity and t-SNE," in Advanced Applied Informatics (IIAI-AAI), 2018 7th International Institute of Applied Informatics (IIAI) International Congress on. Institute of Electrical and Electronics Engineers (IEEE), 2018, pp. 390-395.

[5] MEXT, "Towards the qualitative transformation of university education in order to build a new future," The Central Council for Education, 2012. [Online]. Available: http://www.mext.go.jp/b_menu/shingi/chukyo/chukyo0/toushin/1325047.htm. [Accessed: 15-Mar-2018].

[6] MEXT, "Construction of education for university," The Central Council for Education, 2008. [Online]. Available:

http://www.mext.go.jp/b_menu/shingi/chukyo/chukyo4/houkoku/080410.htm. [Accessed: 15-Mar-2018].

[7] K. Takamatsu et al., "SWOT analysis and complex network analysis to enhance governance in universities by collaboration between faculty and staff," in Advanced Applied Informatics (IIAI-AAI), 2016 5th International Institute of Applied Informatics (IIAI) International Congress on. Institute of Electrical and Electronics Engineers (IEEE), 2016, pp. 1188-1189.

[8] K. Takamatsu et al., "A new way of visualizing curricula using competencies: Cosine similarity, multidimensional scaling methods, and scatter plotting," in Advanced Applied Informatics (IIAI-AAI), 2017 6th International Institute of Applied Informatics (IIAI) International Congress on. Institute of Electrical and Electronics Engineers (IEEE), 2017, pp. 192-197.

[9] M. Seki et al., "Generic Support System Prototype in Eduinformatics for Students Selecting a Seminar," in Advanced Applied Informatics (IIAI-AAI), 2018 7th International Institute of Applied Informatics (IIAI) International Congress on. Institute of Electrical and Electronics Engineers (IEEE), 2018, pp. 470-473.

[10] UNESCO, “Learning Analytics,” 2012.

[11] D. Norris, L. Baer, J. Leonard, L. Pugliese, and P. Lefrere, "Action analytics: Measuring and improving performance that matters in higher education," Educ. Rev., vol. 43, no. 1, p. 42, 2008.

[12] “DQC: Data Quality Campaign.” [Online]. Available: https://dataqualitycampaign.org/. [Accessed: 01-Apr-2018].

[13] J. P. Campbell, P. B. DeBlois, and D. G. Oblinger, "Academic analytics: A new tool for a new era," Educ. Rev., vol. 42, no. 4, p. 40, 2007.

[14] MEXT, "Toward the construction of undergraduate education (Japanese)," Central Council for Education, 2008. [Online]. Available:

http://www.mext.go.jp/b_menu/shingi/chukyo/chukyo4/houkoku/080410.htm. [Accessed: 15-Mar-2020]. 
[15] Between Editorial Department, "Connection between three policies (Japanese)," between, p. 1, 2008.

[16] T. Kirimura et al., "Innovate the management of teaching and learning at our own university through collaboration between academic faculty and administrative staff," Bull. Kobe Tokiwa Univ., vol. 10, pp. 23-32, 2017.

[17] T. Kirimura, K. Takamatsu, K. Bannaka, I. Noda, K. Mitsunari, and Y. Nakata, "Design the basic education courses as part of the innovation of management of learning and teaching at our own university through collaboration between academic and administrative faculty," Bull. Kobe Tokiwa Univ., vol. 11, pp. 181-192, 2018.

[18] “Syllabus of Kobe Tokiwa University," Kobe Tokiwa University, 2017. [Online]. Available: available: http://www.kobe-tokiwa.ac.jp/univ/. [Accessed: 15Mar-2020].

[19] T. Kirimura et al., "Effectiveness of first year experience's course 'Manaburu' at Kobe Tokiwa University for university students by using textual analysis," Bull. Kobe Tokiwa Univ., vol. 11, pp. 193-208, 2018.

[20] R Core Team, "R: A Language and Environment for Statistical Computing," $R$ Foundation for Statistical Computing, Vienna, Austria, vol. 0. p. \{ISBN\} 3-9000517-0, 2017.

[21] RStudio Team, "RStudio: Integrated Development for R. RStudio, Inc., Boston, MA. URL http://www.rstudio.com/.," RStudio, Inc., 2015.

[22] A. Eklund, "beeswarm: The Bee Swarm Plot, an Alternative to Stripchart." 2016.

[23] T. L. Weissgerber, N. M. Milic, S. J. Winham, and V. D. Garovic, "Beyond bar and line graphs: time for a new data presentation paradigm," PLoS Biol, vol. 13, no. 4, p. e1002128, 2015.

[24] Y. Nakata et al., "Ensuring Equal Evaluation among Teachers in First-Year Education Courses through Rubrics: A Multiple Comparison Analysis," in International Conference on Education, Psychology, and Learning (ICEPL2018), 2018, pp. 4046.

[25] T. Kunihiko et al., "Web-based Support System for Students to Select Courses using Tokiwa Competencies," in International Conference on Education, Psychology, and Learning (ICEPL2017), 2017, pp. 74-80.

[26] K. Takamatsu et al., "A Novel Curriculum Visualization Method Using a Combination of Competencies, Cosine Similarity, Multidimensional Scaling Methods, and Scatter Plotting," IEE Inf. Eng. Express, vol. 5, no. 1, pp. 127-143, 2019. 
[27] K. Takamatsu, K. Murakami, T. Oshiro, A. Sugiura, K. Bannaka, and Y. Nakata, "Predicting the Probability of Student's Academic Abilities and Progress with EMIR and Data from Current and Graduated Students," in Advanced Applied Informatics (IIAI-AAI), 2019 8th International Institute of Applied Informatics (IIAI) International Congress on. Institute of Electrical and Electronics Engineers (IEEE), 2019, pp. 359-362.

[28] Y. Nakata et al., "New Proposal to Compare Student Data in Institutional Research," in Advanced Applied Informatics (IIAI-AAI), 2019 8th International Institute of Applied Informatics (IIAI) International Congress on. Institute of Electrical and Electronics Engineers (IEEE), 2019, pp. 404-407.

[29] K. Takamatsu et al., "Introducing new criteria for IR, using student data compared analysis based on Eduinformatics," in Advanced Applied Informatics (IIAI-AAI), 2020 9th International Institute of Applied Informatics (IIAI) International Congress on. Institute of Electrical and Electronics Engineers (IEEE), 2020, pp. 378384. 